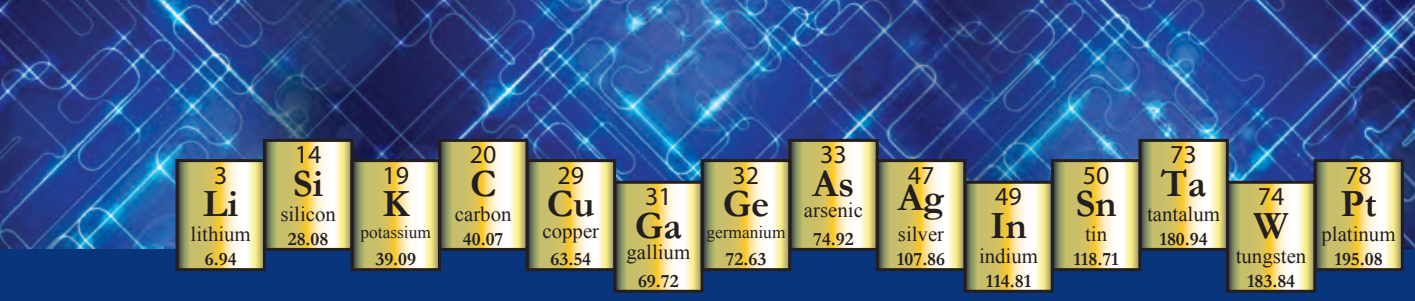

\title{
A World of Minerals in Your Mobile Device
}

Mobile phones and other high-technology communications devices could not exist without mineral commodities. More than one-half of all components in a mobile device - including its electronics, display, battery, speakers, and more — are made from mined and semi-processed materials (mineral commodities). Some mineral commodities can be recovered as byproducts during the production and processing of other commodities. As an example, bauxite is mined for its aluminum content, but gallium is recovered during the aluminum production process. The images below show the ore minerals (sources) of some mineral commodities that are used to make components of a mobile device. On the reverse side, the map and table depict the major source countries producing some of these mineral commodities along with how these commodities are used in mobile devices. For more information on minerals, visit http://minerals.usgs.gov.

\section{Display}

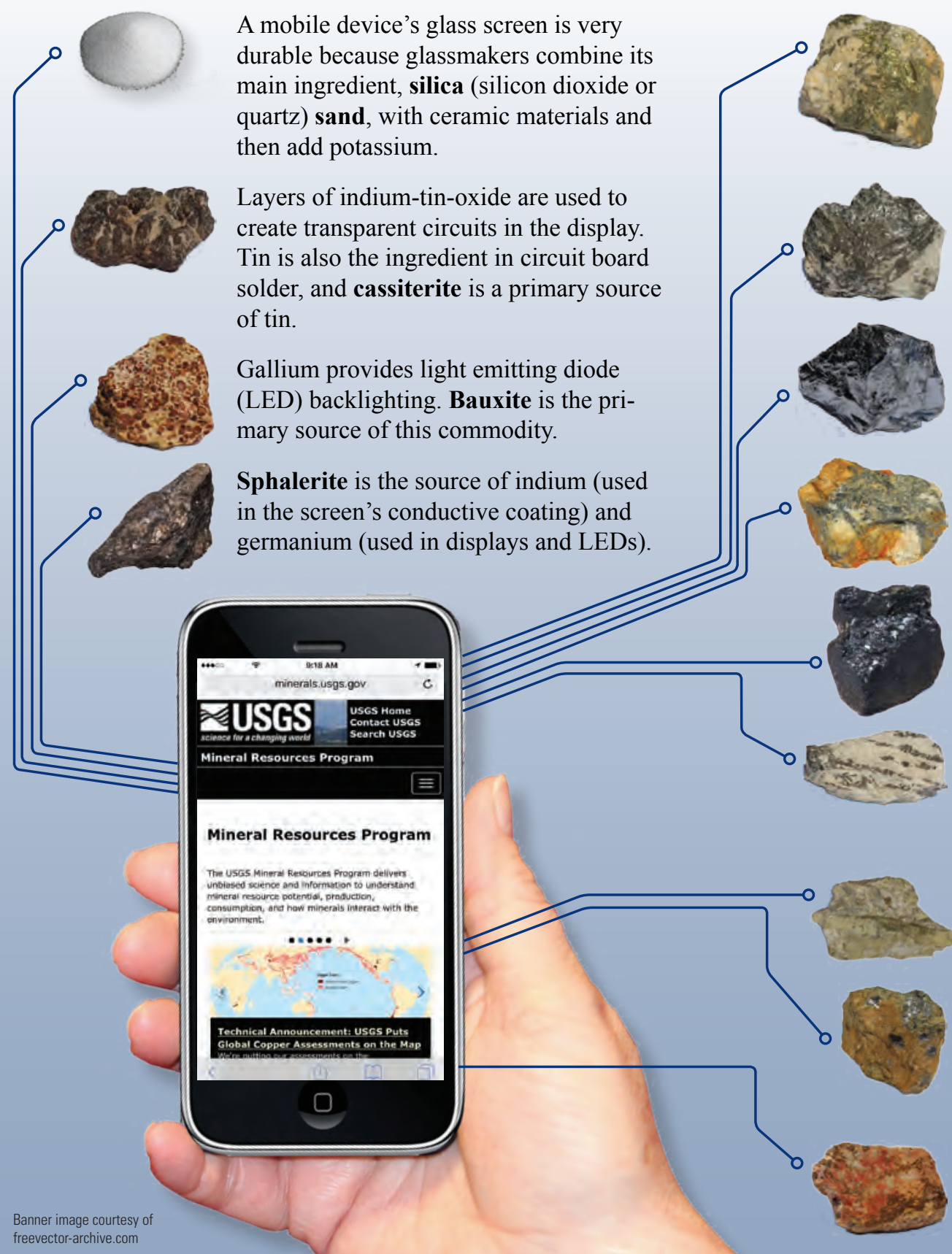

\section{Electronics and Circuitry}

The content of copper in a mobile device far exceeds the amount of any other metal. Copper conducts electricity and heat and comes from the source mineral chalcopyrite.

Tetrahedrite is a primary source of silver. Silver-based inks on composite boards create electrical pathways through a device.

Silicon, very abundant in the Earth's crust, is produced from the source mineral quartz and is the basis of integrated circuits.

Arsenopyrite is a source of arsenic, which is used in radio frequency and power amplifiers.

Tantalum, from the source mineral tantalite, is added to capacitors to regulate voltage and improve the audio quality of a device.

Wolframite is a source of tungsten, which acts as a heat sink and provides the mass for mobile phone vibration.

\section{Battery}

Spodumene and subsurface brines are the sources of lithium used in cathodes of lithium-ion batteries.

Graphite is used for the anodes of lithium-ion batteries because of its electrical and thermal conductivity.

\section{Speakers and Vibration}

Bastnaesite is a source of rare-earth elements used to produce magnets in speakers, microphones, and vibration motors. 
Leading sources of mineral commodities used in mobile devices

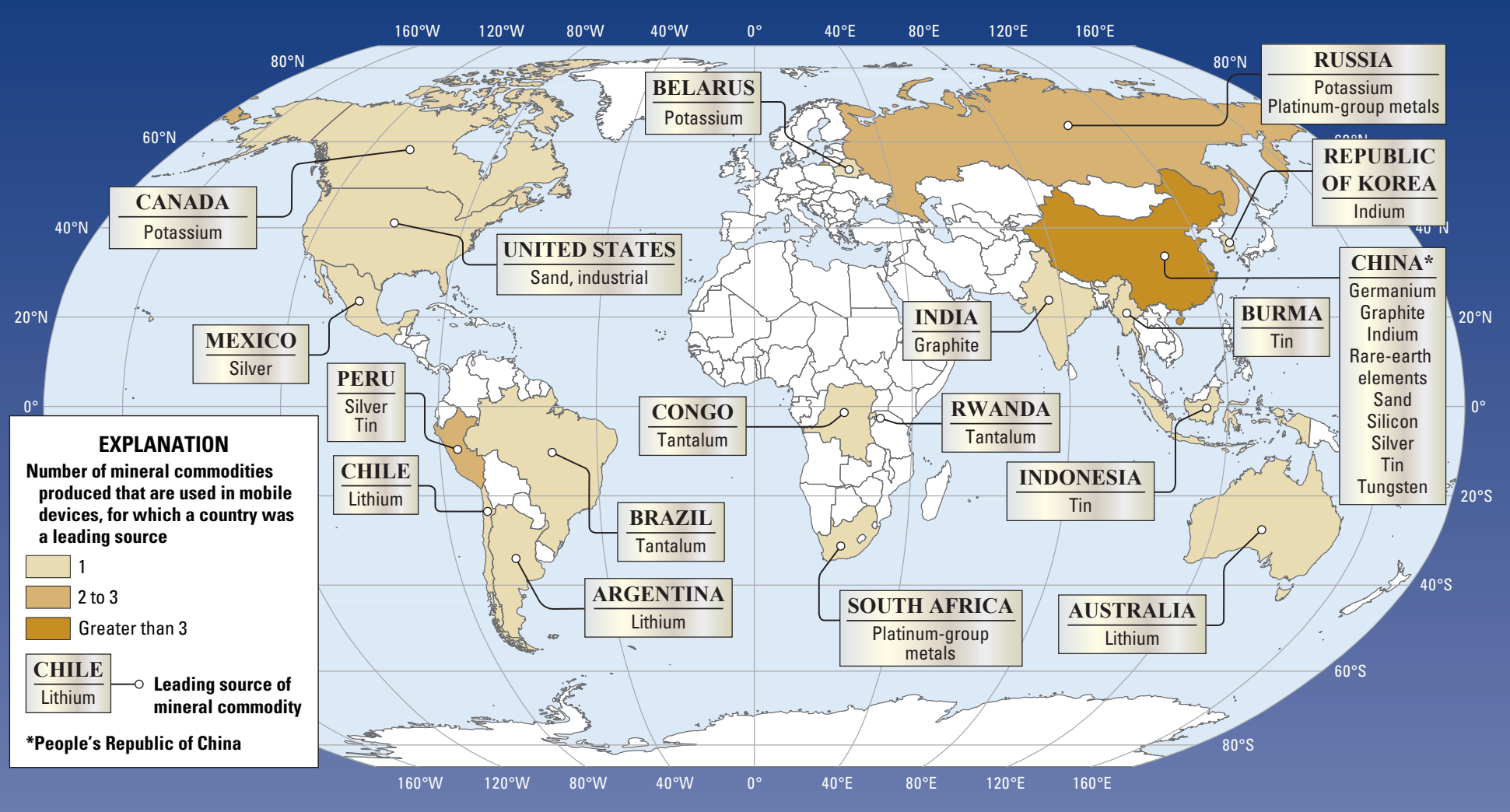

Examples of mineral commodities used in mobile devices

\begin{tabular}{|c|c|c|c|c|}
\hline $\begin{array}{l}\text { Mineral } \\
\text { commodity }\end{array}$ & $\begin{array}{l}\text { Leading global sources } \\
\text { by decreasing tonnage } \\
\text { in } 2014\end{array}$ & Mineral source(s) & Applicable properties of the commodity & $\begin{array}{l}\text { Where the commodities are } \\
\text { used in a mobile device }\end{array}$ \\
\hline Germanium & China $^{1}$ & Sphalerite & Conducts electricity & $\begin{array}{l}\text { Battery, display, electronics and } \\
\text { circuitry, and vibration components. }\end{array}$ \\
\hline Graphite & China, India & Graphite & $\begin{array}{l}\text { Resists heat, conducts electricity and } \\
\text { heat, resists corrosion, and has a high } \\
\text { performance-to-weight ratio }\end{array}$ & Battery anodes. \\
\hline Indium & China, Republic of Korea & Sphalerite & Transparent and conducts electricity & Liquid crystal displays. \\
\hline Lithium & $\begin{array}{l}\text { Australia, Chile, } \\
\text { Argentina, China }\end{array}$ & $\begin{array}{l}\text { Amblygonite, petalite, lepidolite, } \\
\text { and spodumene }\end{array}$ & $\begin{array}{l}\text { Chemically reactive and has a high } \\
\text { performance-to-weight ratio }\end{array}$ & Battery cathodes. \\
\hline $\begin{array}{l}\text { Platinum-group } \\
\text { metals }\end{array}$ & $\begin{array}{l}\text { South Africa, Russia, } \\
\text { Canada }\end{array}$ & More than 100 different minerals & Conducts electricity & Circuitry, capacitors, and plating. \\
\hline Potassium & Canada, Russia, Belarus & Langbeinite, sylvite, and sylvinite & Strengthens glass & Screen glass. \\
\hline $\begin{array}{l}\text { Rare-earth } \\
\text { elements }\end{array}$ & China & $\begin{array}{l}\text { Bastnäsite, ion adsorption clays, } \\
\text { loparite, monazite, and xenotime }\end{array}$ & $\begin{array}{l}\text { Highly magnetic; blue, green, red, and } \\
\text { yellow phosphors; and optical-quality glass }\end{array}$ & $\begin{array}{l}\text { LED phosphors, screens, speakers, } \\
\text { and vibration motors. }\end{array}$ \\
\hline Sand, industrial & China, ${ }^{2}$ United States & Silica sand & Gives glass clarity & Screen glass and semiconductors. \\
\hline Silicon & China & Quartz & Conducts electricity & Semiconductors. \\
\hline Silver & Mexico, China, Peru & Argentite and tetrahedrite & Conducts electricity & Circuitry. \\
\hline Tantalum & $\begin{array}{l}\text { Rwanda, Brazil, } \\
\text { Congo (Kinshasa) }\end{array}$ & Columbite and tantalite & Stores electrical charge well & Capacitors. \\
\hline Tin & $\begin{array}{l}\text { China, Indonesia, Burma, } \\
\text { Peru }\end{array}$ & Cassiterite & Transparent and conducts electricity & $\begin{array}{l}\text { Liquid crystal displays and circuit } \\
\text { board solder. }\end{array}$ \\
\hline Tungsten & China & Scheelite and wolframite & $\begin{array}{l}\text { Highly dense and durable for vibrator's } \\
\text { weight component }\end{array}$ & Vibrator. \\
\hline
\end{tabular}

'People's Republic of China, hereinafter referred to as China.

${ }^{2}$ China is the world's largest producer of industrial sand; however, available information is inadequate to formulate a reliable estimate of output levels.

\section{For more information, contact:}

Mineral Resources Program Coordinator U.S. Geological Survey

913 National Center 12201 Sunrise Valley Drive

Reston, VA 20192
Phone: 703-648-6100

Email: minerals@usgs.gov

Or visit the USGS Mineral Resources Program Web site at

http://minerals.usgs.gov

Follow us on Twitter and Instagram: @usgsminerals
ISSN 2332-3531 (print) ISSN 2332-354X (online) http://dx.doi.org/10.3133/gip167 